Provided for non-commercial research and education use. Not for reproduction, distribution or commercial use.

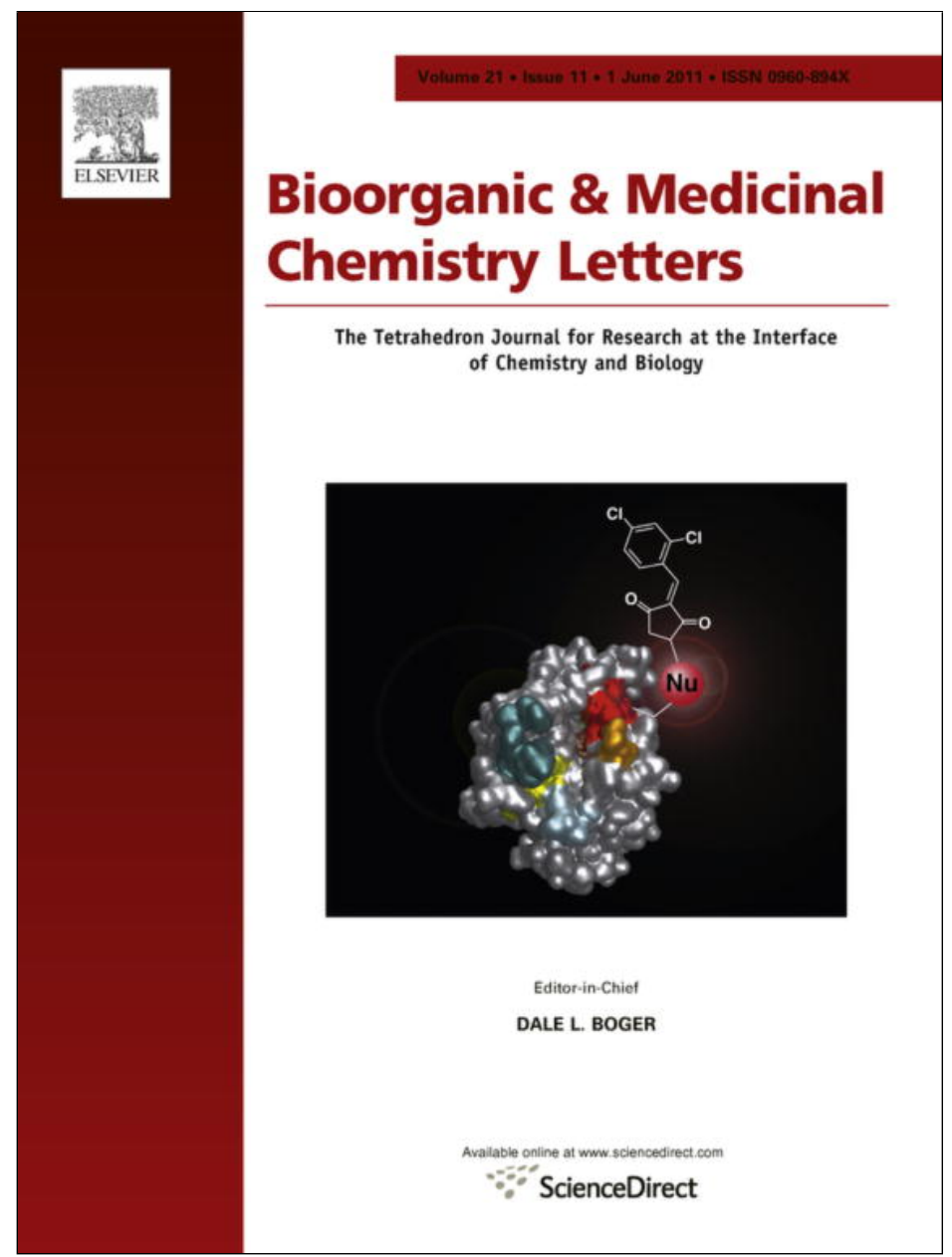

This article appeared in a journal published by Elsevier. The attached copy is furnished to the author for internal non-commercial research and education use, including for instruction at the authors institution and sharing with colleagues.

Other uses, including reproduction and distribution, or selling or licensing copies, or posting to personal, institutional or third party websites are prohibited.

In most cases authors are permitted to post their version of the article (e.g. in Word or Tex form) to their personal website or institutional repository. Authors requiring further information regarding Elsevier's archiving and manuscript policies are encouraged to visit:

http://www.elsevier.com/copyright 


\title{
Synthesis and in vitro antimicrobial activities of new (cyano-NNO-azoxy) pyrazole derivatives
}

\author{
Donatella Boschi ${ }^{\mathrm{a}, *}$, Stefano Guglielmo ${ }^{\mathrm{a}}$, Stefania Aiello ${ }^{\mathrm{b}}$, Giulia Morace ${ }^{\mathrm{c}}$, Elisa Borghi ${ }^{\mathrm{c}}$, Roberta Fruttero ${ }^{\mathrm{a}}$ \\ ${ }^{a}$ Dipartimento di Scienza e Tecnologia del Farmaco, Università di Torino, via Pietro Giuria 9, I-10125 Turin, Italy \\ b Dipartimento Farmacochimico Tossicologico e Biologico, Università degli Studi, via Archirafi 32, I-90123 Palermo, Italy \\ ${ }^{\mathrm{c}}$ Dipartimento di Sanità pubblica-Microbiologia-Virologia, Università degli Studi di Milano, via C. Pascal 36, I-20133 Milan, Italy
}

\section{A R T I C L E I N F O}

\section{Article history:}

Received 31 January 2011

Revised 25 March 2011

Accepted 29 March 2011

Available online 5 April 2011

\section{Keywords:}

Antifungal activity

Pyrazole

Azole resistance

Cyano-NNO-azoxy

Thiophene

\begin{abstract}
A B S T R A C T
The antibacterial and antifungal activity of a series of products, in which the 1,5-dimethyl-4-(cyanoNNO-azoxy)pyrazol-3-yl and 1,3-dimethyl-4-(cyano-NNO-azoxy)pyrazol-5-yl moieties were linked to pyridine, pyrazole, isoxazole, thiophene and the furan ring, were examined. No molecule displayed activity against the Gram-negative bacteria tested. Conversely, some compounds displayed activity against two Staphylococcus aureus strains, including the methicillin resistant strain. All compounds displayed interesting antifungal activity, the most active compound of the series being the thiophene derivative 7a. This compound's activity against Candida krusei and Candida glabrata (MIC $=0.25$ and $0.5 \mu \mathrm{g} / \mathrm{mL}$, respectively), two fungal species resistant to azoles, is noteworthy. The presence of the cyano function appeared essential for activity.
\end{abstract}

(c) 2011 Elsevier Ltd. All rights reserved.
The azoxycyanide functional group $(-\mathrm{N}(\mathrm{O})=\mathrm{N}-\mathrm{CN})$ was originally discovered in the antibiotic calvatic acid (4-carboxyphenyl-ONNazoxycyanide, 4-(cyano-NNO-azoxy)benzoic acid), which was first isolated from a culture broth of Calvatia lilacina (BERK.) Henn. P., ${ }^{1}$ then from cultures of Calvatia craniformis (SHW.) Fr., and Lycoperdon pyriforme. ${ }^{3}$

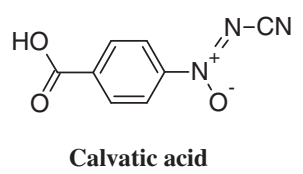

Calvatic acid displays significant antifungal and antibacterial activity, as well as in vitro and in vivo antitumor activity. ${ }^{2,4}$ It also has activity against a number of strains of Helicobacter pylori, including metronidazole resistent ones. ${ }^{5}$ The antibiotic also shows a range of specific biological functions; among these are inhibition of $\left[{ }^{3} \mathrm{H}\right]$ colchicine binding to soluble tubulin, inhibition of human placenta glutathione transferase, as well as of ornithine decarboxylase. ${ }^{6-8}$ The structure of Calvatic acid has been used as a starting point in several other studies; in particular, the azoxycyanide function has been inserted in a variety of aryl and heteroaryl vectors. ${ }^{9-13}$ The resulting compounds displayed the general activities of the lead, but with a range of potency and specificity. They are superior antifungal agents compared to the parent compound. These deriv-

\footnotetext{
* Corresponding author. Tel.: +39 011670 7674; fax: +390116707286.

E-mail address: donatella.boschi@unito.it (D. Boschi).
}

atives have also been examined as potential agricultural fungicides. ${ }^{14}$ The results are reported of a study of the antibacterial and antifungal activity of a series of products in which the 1,5-dimethyl-4-(cyano-NNO-azoxy)pyrazol-3-yl and 1,3-dimethyl-4-(cyano-NNO-azoxy)pyrazol-5-yl moieties $\mathrm{R}^{3}$ and $\mathrm{R}^{5}$ (Table 1 ) were linked to pyridine, pyrazole, isoxazole, thiophene and furan ring. In order to elucidate the significance of the cyano function on activity, the carbamoyl $\mathbf{1 0}$ and tosyl $\mathbf{1 1}$ analogues of 7a, the most active compound of the series, were also examined.

Scheme 1 outlines the preparation of the final azoxycyano derivatives. The starting materials were the 1-methyl-4-nitrosopyrazoles derivatives 1-9, bearing methyl and heteroaryl substituents at 3- and 5- positions. These products were transformed into the final compounds by regiospecific synthesis, as described by Fruttero et al. ${ }^{15}$ and later modified by Wood et al, ${ }^{13}$ with the exception of the oxidative-breakdown-susceptible furan derivative 9a, for which the procedure was partially modified. Nitrosoderivatives were treated in dry $\mathrm{CH}_{2} \mathrm{Cl}_{2}$ with a mixture of cyanamide $\left(\mathrm{NH}_{2} \mathrm{CN}\right)$ and (diacetoxy)iodobenzene (IBA), giving the expected final products, probably through the intermediate formation of cyanonitrene. All products showed the fragment ions $[\mathrm{M}-40]^{+}$in their mass spectra, due to loss of $\mathrm{CN}_{2}$, typical of this class of compounds. ${ }^{16}$ Compound $\mathbf{1 0}$ was easily obtained by bubbling $\mathrm{HCl}$ through a $\mathrm{THF} / \mathrm{H}_{2} \mathrm{O}$ solution of $\mathbf{7 a}$, following the general procedure described elsewhere, ${ }^{12}$ while compound $\mathbf{1 1}$ was synthesized by action of the nitrene precursor $\mathrm{N}$-tosyliminoiodinane, prepared by a known procedure, ${ }^{17}$ on $\mathbf{7}$ dissolved in acetonitrile containing activated $4 \AA$ molecular sieves (MS) and $\mathrm{CuCl}$ (Scheme 2). 


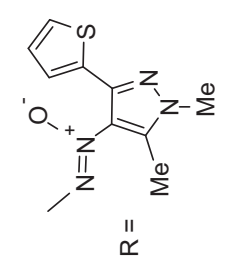

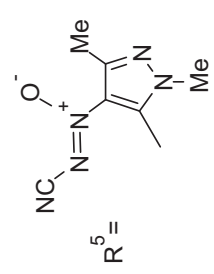<smiles>CC1=C(C)C(=C(O)CO)C(C)=C1C</smiles>

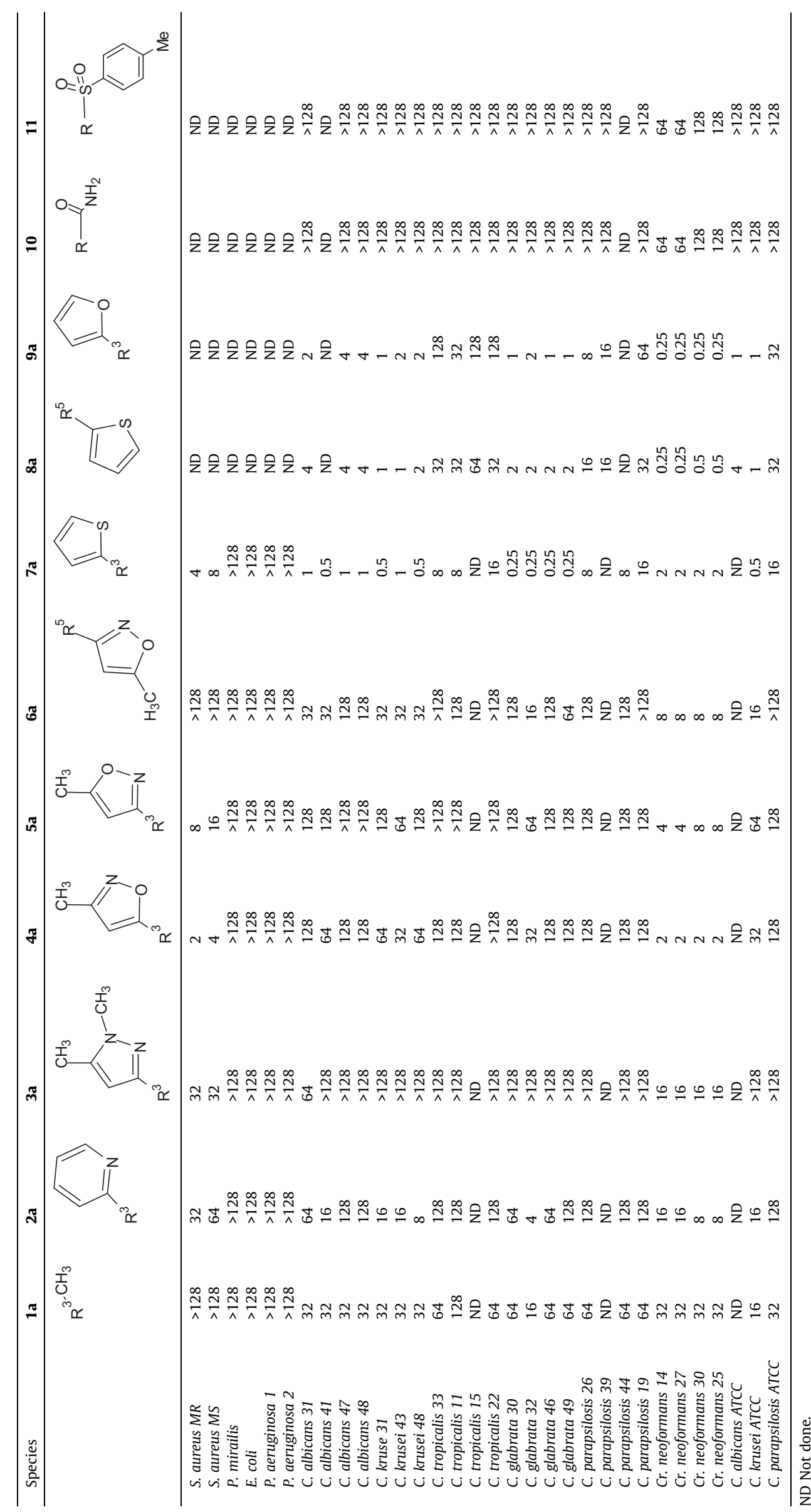




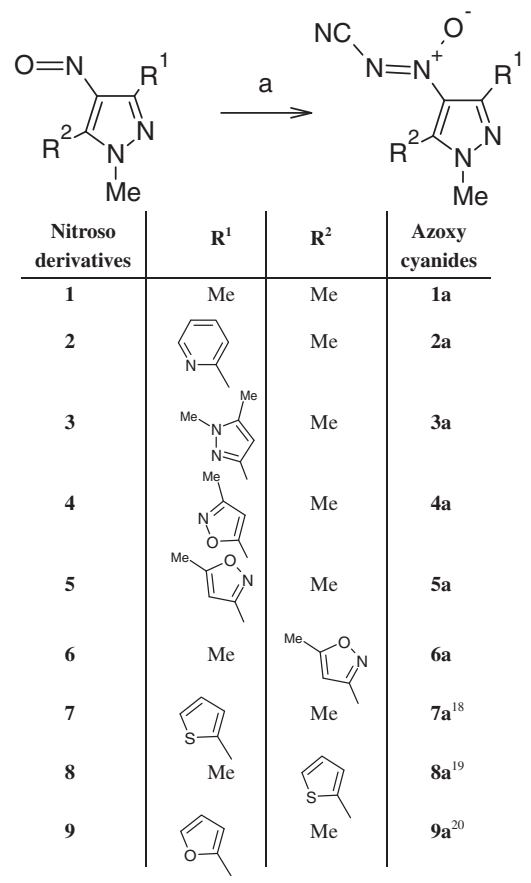

Scheme 1. Reagents and conditions: (a) $\mathrm{NH}_{2} \mathrm{CNNH}_{2} \mathrm{CN}$, (diacetoxy)iodobenzene (IBA), dry $\mathrm{CH}_{2} \mathrm{Cl}_{2}, 30^{\circ} \mathrm{C}$.

The first seven products were tested against two strains of Staphylococcus aureus, one resistant (MR) and the other susceptible (MS) to methicillin, three species of Gram-negative bacteria, Proteus mirabilis, Escherichia coli and Pseudomonas aeruginosa, six fungal species belonging to Candida spp., and Cryptococcus neoformans<smiles>Cc1c(-c2cccs2)nn(C)c1/C=[N+](/[O-])NC(N)=O</smiles>

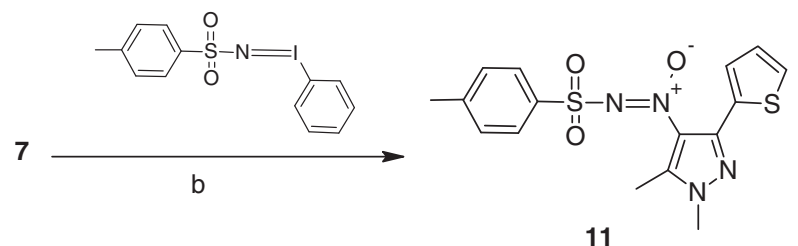

11

Scheme 2. Reagents and conditions: (a) $\mathrm{HCl}$ gas, $\mathrm{THF} / \mathrm{H}_{2} \mathrm{O}, 0^{\circ} \mathrm{C}$. (b) $\mathrm{N}$-tosyliminoiodinane, $\mathrm{CuCl}, 4 \AA \mathrm{A} \mathrm{MS}$, dry acetonitrile, rt.

var. neoformans. Because both yeasts and $S$. aureus can be normal microbiota of human mucosa and skin, the yeasts and the two $S$. aureus isolates used in this study were collected from human sterile clinical specimens (blood and cerebrospinal fluid), Gram-negative bacteria were isolated from urine having a colony forming unit (CFU) count above the cutoff of $>10^{5} \mathrm{CFU}$. Antimicrobial assays were performed with a microdilution broth method, following standard protocols for in vitro antibacterial and antifungal susceptibility testing. ${ }^{21,22}$ The results are in Table $1^{23}$.

The antimicrobial data showed that none of the molecules displayed activity against the Gram negative bacteria tested. Conversely, except for $\mathbf{1 a}$ and $\mathbf{6 a}$, they displayed some activity against both $S$. aureus strains, including the MR strain, against

Table 2

Comparison of in vitro activities of the designed compounds with that of the widely used systemic antifungal drugs (MIC, $\mu \mathrm{g} / \mathrm{mL}$ )

\begin{tabular}{|c|c|c|c|c|c|c|c|}
\hline Species & $7 a$ & $8 a$ & 9a & Fluconazole & Voriconazole & Posaconazole & Amphotericinb \\
\hline C. albicans 31 & 1 & 4 & 2 & 0.25 & $<0.008$ & 0.008 & 0.5 \\
\hline C. albicans 41 & 0.5 & ND & ND & 0.12 & $<0.008$ & 0.016 & 0.5 \\
\hline C. albicans 47 & 1 & 4 & 4 & 0.25 & 0.008 & 0.016 & 1 \\
\hline C. albicans 48 & 1 & 4 & 4 & 0.12 & $<0.008$ & 0.008 & 0.5 \\
\hline C. krusei 31 & 0.5 & 1 & 1 & 32 & 0.12 & 0.25 & 0.5 \\
\hline C. krusei 43 & 1 & 1 & 2 & 64 & 0.5 & 0.5 & 1 \\
\hline C. krusei 48 & 0.5 & 2 & 2 & 32 & 0.25 & 0.25 & 1 \\
\hline C. tropicalis 33 & 8 & 32 & 128 & 1 & $<0.008$ & 0.12 & 1 \\
\hline C. tropicalis 11 & 8 & 32 & 32 & 1 & 0.12 & 0.12 & 1 \\
\hline C. tropicalis 15 & ND & 64 & 128 & 1 & 0.06 & 0.25 & 1 \\
\hline C. tropicalis 22 & 16 & 32 & 128 & 2 & 0.06 & 0.25 & 0.5 \\
\hline C. glabrata 30 & 0.25 & 2 & 1 & 8 & 0.25 & 0.5 & 1 \\
\hline C. glabrata 32 & 0.25 & 2 & 2 & $>256$ & 4 & $>8$ & 0.5 \\
\hline C. glabrata 46 & 0.25 & 2 & 1 & 16 & 0.25 & 1 & 1 \\
\hline C. glabrata 49 & 0.25 & 2 & 1 & 8 & 0.12 & 0.25 & 0.5 \\
\hline C. parapsilosis 26 & 8 & 16 & 8 & 1 & $<0.008$ & 0.03 & 0.5 \\
\hline C. parapsilosis 39 & ND & 16 & 16 & 1 & 0.016 & 0.06 & 0.5 \\
\hline C. parapsilosis 44 & 8 & ND & ND & 2 & 0.016 & 0.03 & 0.5 \\
\hline C. parapsilosis 19 & 16 & 32 & 64 & 1 & 0.008 & 0.03 & 0.5 \\
\hline Cr. neoformans 14 & 2 & 0.25 & 0.25 & 0.5 & $<0.008$ & 0.03 & 0.25 \\
\hline Cr. neoformans 27 & 2 & 0.25 & 0.25 & 2 & 0.016 & 0.06 & 0.12 \\
\hline Cr. neoformans 30 & 2 & 0.5 & 0.25 & 4 & 0.016 & 0.12 & 0.5 \\
\hline Cr. neoformans 25 & 2 & 0.5 & 0.25 & 2 & 0.016 & 0.06 & 0.5 \\
\hline C. albicans ATCC & ND & 4 & 1 & 0.12 & 0.008 & 0.008 & 0.5 \\
\hline C. krusei ATCC & 0.5 & 1 & 1 & 32 & 0.25 & 0.25 & 1 \\
\hline C. parapsilosis ATCC & 16 & 32 & 32 & 2 & 0.06 & 0.12 & 1 \\
\hline
\end{tabular}


which erythromycin and ciprofloxacin are also inactive, as determined following the established clinical breakpoint $\geqslant 1 \mu \mathrm{g} / \mathrm{mL}$

From this standpoint, the lowest MIC values were displayed by derivatives $\mathbf{4 a}, \mathbf{5 a}$, and $\mathbf{7 a}$, respectively bearing the 3-methyl-5oxazolyl, 5-methyl-3-oxazolyl, and thiophen-2-yl substituent at the 3-position of the pyrazolylazoxycyanide scaffold $\mathrm{R}^{3}$. As far as antifungal activity is concerned, the most active product was 7a: this is a potent antifungal product active against almost all the species tested. Candida parapsilosis and Candida tropicalis isolates had higher MIC values than those of the other yeasts tested. The activity against Candida krusei, which displays intrinsic fluconazole resistance, and against Candida glabrata, which has acquired resistance to azoles, are of note (Table 2). ${ }^{24}$ When the thienyl substituent was moved to position 5 of the pyrazole ring, to give compound 8a, the level of activity remained high, MIC values being within $\pm 2 \log _{2}$ dilutions. Compound 8a was particularly active against the strains of Cryptococcus neoformans, which was susceptible to all the pyrazolylazoxycyanide derivatives tested. When in 7a the furan moiety was substituted for the thiophene, giving compound 9a, activity against all the species under study remained high, declining only for the strains of $C$. tropicalis. The presence of the azoxycyano function in these products appeared to be essential to their activity: the cyano group was substituted in $7 \mathbf{a}$ with two other electron-withdrawing moieties, the carbamoyl and the tosyl moiety respectively, giving products $\mathbf{1 0}$ and 11, which were inactive.

In conclusion, interesting pyrazole derivatives displaying antifungal activity were developed. In particular, compounds 7a, 8a, 9a deserve further structural modulation, owing to their potent action against $C$. krusei and $C$. glabrata, two fungal species resistant to azoles.

\section{Supplementary data}

Supplementary data (synthesis of intermediates $\mathbf{7 , 8}$, full experimental procedures, physicochemical characterization, and elemental analyses for the compounds described, is available free of charge via the Internet at http://) associated with this article can be found, in the online version, at doi:10.1016/j.bmcl.2011.03.101.

\section{References and notes}

1. Gasco, A.; Serafino, A.; Mortarini, V.; Menziani, E.; Bianco, M. A.; Ceruti Scurti, J Tetrahedron Lett. 1974, 15, 3431.

2. Umezawa, H.; Takeuchi, T.; Linuma, H.; Ito, M.; Ishizuka, M.; Kurakata, Y.; Umeda, Y.; Nakanishi, Y.; Nakamura, T.; Obayashi, A.; Tanabe, O. J. Antibiot 1975, 28, 87

3. Okuda, T.; Nakayama, N.; Fujiwara, A. Trans. Mycol. Soc. Jpn. 1982, 23, 225.

4. Bianco, M. A.; Ceruti-Scurti, J. Allionia 1972, 18, 79.

5. Boschi, D.; Cena, C.; Fruttero, R.; Brenciaglia, M. I.; Scaltrito, M. M.; Dubini, F. Gasco, A. Pharmazie 2001, 56, 670.

6. Islam, M. N.; Iskander, M. N. Mini-Rev. Med. Chem. 2004, 4, 1077. and references therein.

7. Caccuri, A. M.; Ricci, G.; Desideri, A.; Buffa, M.; Fruttero, R.; Gasco, A.; Ascenzi, P. Biochem. Mol. Biol. Int. 1994, 32, 819

8. Brossa, O.; Gadoni, E.; Olivero, A.; Seccia, M.; Miglietta, A.; Gabriel, L.; Gravela E. Res. Commun. Chem. Pathol. Pharmacol. 1990, 70, 143.

9. Mortarini, V.; Ruà, G.; Gasco, A.; Bianco, M. A.; Sanfilippo, A. Eur. J. Med. Chem. 1977, 12, 59.

10. Fruttero, R.; Gasco, A.; Tironi, C.; Schioppacassi, G. Eur. J. Med. Chem.- Chim. Ther. 1982, 17, 482 .

11. Fruttero, R.; Tironi, C.; Calvino, R. Pharmazie 1988, 43, 551.

12. Fruttero, R.; Calvino, R.; Distilo, A.; Gasco, A.; Galatulas, I.; Bossa, R. Pharmazie 1988, 43, 499.
13. Wood, W. W.; Kremp, G.; Petry, T.; Simon, W. E. J. Synth. Commun. 1999, 29, 619. and references therein.

14. Gray, A. C. G.; Kremp, G.; Naisby, T. W.; Petry, T.; Simon, W.; Wilkin, J.; Wood, W. W. In Synthesis and Chemistry of Agrochemicals VI, ACS Symposium Series, 2001; Vol. 800, pp 292302.

15. Fruttero, R.; Mulatero, G.; Calvino, R.; Gasco, A. J. Chem. Soc., Chem. Commun. 1984, 323.

16. Vaglio, G. A.; Mortarini, V.; Frattini, C.; Gasco, A. Ann. Chim. Rome 1976, 66, 521

17. Yamada, Y.; Yamamoto, T.; Okawara, M. Chem. Lett. 1975, 4, 361.

18. 4-(Cyano-NNO-azoxy)-1,5-dimethyl-3-(thiophen-2-yl)-1H-pyrazole (7a): FC (petroleum ether/EtOAc 7:3) gives 7a (85\%) as a brown solid. Mp 131-132 ${ }^{\circ} \mathrm{C}$ (EtOAc/hexane). IR (KBr DRIFT/cm $\left.{ }^{-1}\right): 2195(\mathrm{C} \equiv \mathrm{N}), 1460,1326(\mathrm{~N}(\mathrm{O})=\mathrm{N}) \cdot{ }^{1} \mathrm{H}$ NMR $\left(\mathrm{CDCl}_{3}, 300 \mathrm{MHz}\right) \delta(\mathrm{ppm}): 7.72\left(\mathrm{dd},{ }^{3} \mathrm{~J}=3.7 \mathrm{~Hz},{ }^{4} \mathrm{~J}=1.2 \mathrm{~Hz} 1 \mathrm{H}, \mathrm{Th}\right), 7.43$ (dd, $\left.{ }^{3} J=5.1 \mathrm{~Hz},{ }^{4} J=1.2 \mathrm{~Hz}, 1 \mathrm{H}, \mathrm{Th}\right), 7.11\left(\mathrm{dd},{ }^{3} J=5.1 \mathrm{~Hz}\right.$ and $\left.3.7 \mathrm{~Hz}, 1 \mathrm{H}, \mathrm{Th}\right)$, $3.90\left(\mathrm{~s}, 3 \mathrm{H}, 1-\mathrm{CH}_{3}-\mathrm{Pz}\right), 2.66\left(\mathrm{~s}, 3 \mathrm{H}, 5-\mathrm{CH}_{3}-\mathrm{Pz}\right) .{ }^{13} \mathrm{C} \mathrm{NMR}\left(\mathrm{CDCl}_{3}, 75 \mathrm{MHz}\right) \delta$ (ppm): 141.7, 140.7, 131.3, 129.8, 128.1, 127.5, 126.4, 110.8, 37.6, 12.6. ES-MS $(70 \mathrm{eV}, \mathrm{m} / \mathrm{z}): 247\left(\mathrm{M}^{+}, 100 \%\right) 207(\mathrm{M}-40)$. Anal. Calcd for $\mathrm{C}_{10} \mathrm{H}_{9} \mathrm{~N}_{5} \mathrm{OS}: \mathrm{C}, 48.57$; H, 3.67; N, 28.32. Found: C, 48.54; H, 3.71; N, 28.14.

19. 4-(Cyano-NNO-azoxy)-1,3-dimethyl-5-(thiophen-2-yl)-1H-pyrazole (8a): genera procedure was modified as follows: acetonitrile as reaction solvent, $50{ }^{\circ} \mathrm{C}$ reaction temperature, 1:1 nitroso/IBA molar ratio. FC (hexane/EtOAc 75:25) gives 8a (30\%) as a brown solid. Mp 92-93 ${ }^{\circ} \mathrm{C} \mathrm{dec}$. (EtOAc/hexane). IR ( $\mathrm{KBr}$ DRIFT $\left./ \mathrm{cm}^{-1}\right): 2185(\mathrm{C} \equiv \mathrm{N}), 1458,1367(\mathrm{~N}(\mathrm{O})=\mathrm{N}) .{ }^{1} \mathrm{H}$ NMR $\left(\mathrm{CDCl}_{3}, 300 \mathrm{MHz}\right) \delta$ (ppm): $7.63(\mathrm{~d}, J=4.8 \mathrm{~Hz}, 1 \mathrm{H}, \mathrm{Th}), 7.21-7.18(\mathrm{~m}, 2 \mathrm{H}, 2 \mathrm{Th}), 3.75\left(\mathrm{~s}, 3 \mathrm{H}, 1-\mathrm{CH}_{3}\right.$ $\mathrm{Pz}), 2.55$ (s, 3H, 3-CH $-\mathrm{Pz}) .{ }^{13} \mathrm{C}$ NMR $\left(\mathrm{CDCl}_{3}, 75 \mathrm{MHz}\right) \delta(\mathrm{ppm}): 146.0,136.1$, $131.5,130.3,128.5,127.6,125.4,110.8,38.1,14.7$. ES-MS $(70 \mathrm{eV}, \mathrm{m} / \mathrm{z}): 247$ $\left(\mathrm{M}^{+}\right) 207(\mathrm{M}-40,100 \%)$. Anal. Calcd for $\mathrm{C}_{10} \mathrm{H}_{9} \mathrm{~N}_{5} \mathrm{OS}$ : C, 48.57; $\mathrm{H}, 3.67 ; \mathrm{N}, 28.32$. Found: C, 48.48; H, 3.59; N, 28.28.

20. 4-(Cyano-NNO-azoxy)-3-(furan-2-yl)-1,5-dimethyl-1H-pyrazole (9a): A mixture of the nitroso-derivative $9(0.57 \mathrm{~g}, 3 \mathrm{mmol})$ and cyanamide $(0.15 \mathrm{~g}, 3.6 \mathrm{mmol})$ in methylene chloride $(5 \mathrm{~mL})$ was treated at $0{ }^{\circ} \mathrm{C}$ with (diacetoxyiodo)benzene $(0.97 \mathrm{~g}, 3 \mathrm{mmol})$ in portions over $15 \mathrm{~min}$. The reaction mixture was directly deposited into the column and purified by $\mathrm{FC}\left(\mathrm{CH}_{2} \mathrm{Cl}_{2} /\right.$ acetone $\left.99.75: 0.25\right)$ to obtain 9a $(0.10 \mathrm{~g}, 14 \%)$ as a yellow solid. Mp $152-154{ }^{\circ} \mathrm{C}$ dec. (EtOH). IR ( $\mathrm{KBr}$ $\left.\mathrm{DRIFT} / \mathrm{cm}^{-1}\right): 2188(\mathrm{C} \equiv \mathrm{N}), 1453,1344(\mathrm{~N}(\mathrm{O})=\mathrm{N}) \cdot{ }^{1} \mathrm{H}$ NMR $\left(\mathrm{CDCl}_{3}, 300 \mathrm{MHz}\right) \delta$ (ppm): $7.56\left(\mathrm{~d},{ }^{3} J=1.5 \mathrm{~Hz}, 1 \mathrm{H}, \mathrm{Fu}\right), 7.22\left(\mathrm{~d},{ }^{3} \mathrm{~J}=3.6 \mathrm{~Hz}, 1 \mathrm{H}, \mathrm{Fu}\right), 6.54$ (dd, ${ }^{3} \mathrm{~J}=3.6 \mathrm{~Hz}$ and $\left.1.5 \mathrm{~Hz}, 1 \mathrm{H}, \mathrm{Fu}\right), 3.95\left(\mathrm{~s}, 3 \mathrm{H}, 1-\mathrm{CH}_{3}-\mathrm{Pz}\right), 2.68\left(\mathrm{~s}, 3 \mathrm{H}, 5-\mathrm{CH}_{3}-\mathrm{Pz}\right) .{ }^{13} \mathrm{C}$ NMR $\left(\mathrm{CDCl}_{3}, 75 \mathrm{MHz}\right) \delta(\mathrm{ppm}): 144.05,143.98,140.5,138.4,126.1,114.2$, 111.7, 110.8, 37.9, 12.7. ES-MS (70 eV, $m / z): 231\left(\mathrm{M}^{+}, 100 \%\right), 191(\mathrm{M}-40$,). Anal. Calcd for $\mathrm{C}_{10} \mathrm{H}_{9} \mathrm{~N}_{5} \mathrm{O}_{2}$ : C, 51.95; $\mathrm{H}, 3.93 ; \mathrm{N}, 30.29$. Found: C, 51.93; H, 3.75; N, 30.18

21. Clinical and laboratory Standards Institute. 2008. M07-A7.

22. Clinical and laboratory Standards Institute. 2008. M27-A3

23. In vitro activity. The yeast isolates used in this study were collected from human sterile clinical specimens (blood and cerebrospinal fluid) to be sure of their pathogenic role. After overnight growth on Sabouraud dextrose agar at $35^{\circ} \mathrm{C}$, each yeast isolate was suspended in $5 \mathrm{~mL}$ of sterile distilled water and thoroughly vortexed to achieve a smooth suspension. Turbidity (read at a wavelength of $530 \mathrm{~nm}$ ) was adjusted to a McFarland standard of 0.5 with water. This suspension (approximately $1-5 \times 10^{6} \mathrm{CFU} / \mathrm{mL}$ ) was used as water. This suspension (approximately $1-5 \times 10^{6} \mathrm{CFU} / \mathrm{mL}$ ) was used as
inoculum for susceptibility testing. Antifungal susceptibility testing was performed with a microdilution broth method using 96-well microtite plates. The wells of each row contained a single compound dissolved in DMSO and diluted in RPMI 1640 medium buffered with MOPS $0.165 \mathrm{M}$ and supplemented with $2 \%$ glucose. Ten wells in the row contained ten different scalar concentrations of the compound, ranging from $0.25 \mathrm{mg} / \mathrm{L}$ to $256 \mathrm{mg} / \mathrm{L}$. For each isolate, the inoculum suspension was diluted twice with RPMI 1640 medium $(1: 100$ and then $1: 20)$. Aliquots $(0.1 \mathrm{~mL})$ of the latter dilution were then placed in 11 wells of a single row ( 10 wells contained the drug, the 11 th as growth control, the 12 th as blank). The plates were incubated at $35^{\circ} \mathrm{C}$. An initial visual examination was made after $24 \mathrm{~h}$ of incubation, and the lowest concentration that had inhibited visible growth was recorded as the MIC. After $48 \mathrm{~h}$ of incubation, the panels were analyzed spectrophotometrically (after shaking), and the MIC was recorded as the concentration that produced a $50 \%$ reduction in turbidity compared with that of the growth-control well. The $48 \mathrm{~h}$ readings were used to analyze results. Three quality control strains were included: C. krusei ATCC ${ }^{\circledR}$ 6258, C. parapsilosis ATCC ${ }^{\circledR}$ 22019, Candida albicans ATCC $^{\circledR}$ 90028. Antibacterial susceptibility was tested as for yeasts, with microdilution broth method using 96-well microtiter plates; Mueller Hinton broth was used instead of RPMI 1640 as medium. After overnight growth on Mueller Hinton broth at $35^{\circ} \mathrm{C}$, each bacterial isolate was diluted to achieve a suspension of approximately $1-5 \times 10^{8} \mathrm{CFU} / \mathrm{mL}$. Aliquots $(0.1 \mathrm{~mL})$ of the latter dilution was then placed in 11 wells of a single row and incubated at $35{ }^{\circ} \mathrm{C}$. Reading was after $24 \mathrm{~h}$ of incubation, and the lowest concentration that had inhibited visible growth was recorded as the MIC.

24. Drago, M.; Scaltrito, M. M.; Morace, G.; Grp, G. Eur. J. Clin. Microbiol. Infect. Dis. 2004, 23, 619. 